\title{
Modelling the hydrologic response of a mesoscale Andean watershed to changes in land use patterns for environmental planning
}

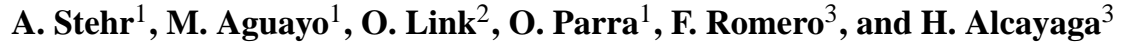 \\ ${ }^{1}$ Environmental Research Center EULA-Chile, Universidad de Concepción, Concepción, Chile \\ ${ }^{2}$ Civil Engineering Department, Universidad de Concepción, Concepción, Chile \\ ${ }^{3}$ National Water Agency, Ministerio de Obras Públicas, Chile \\ Received: 15 April 2010 - Published in Hydrol. Earth Syst. Sci. Discuss.: 18 May 2010 \\ Revised: 24 September 2010 - Accepted: 29 September 2010 - Published: 15 October 2010
}

\begin{abstract}
A multidisciplinary approach is followed for analysis of the effect of changes in land use patterns on the hydrologic response of the Vergara watershed $\left(4340 \mathrm{~km}^{2}\right)$ located in central Chile. Probable future land use scenarios were generated using heuristic rules and logistic regression models, in order to identify and represent the main pressure on the watershed, namely forestation of extensive areas used for agriculture with rapid growing exotic species. The hydrologic response of the watershed was computed with a physically based distributed precipitation-runoff model, which was calibrated and validated for the current period. Results show that mean annual discharge increase with agricultural land use and diminish with introduced forest coverage. Thus, forestation of areas with introduced species like Pinus radiata and Eucalyptus globulus might be regulated in order to protect the water resources of the watershed.
\end{abstract}

\section{Introduction}

Water is essential for human life and welfare, and its demand is increasing. Many people worldwide are already living in conditions of water scarcity, and with increasing concentration of population in urban areas, future water supply and availability is a globally sensitive issue (Jenerette and Larsen, 2006). Provision of clean water, as an essential ecosystem service, is a crucial factor in watershed/catchments management (Mark and Dickinson, 2008). Land use and climate changes introduce additional complexity in the management

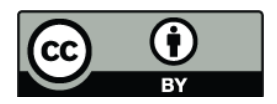

Correspondence to: A. Stehr (astehr@udec.cl) process. A challenging issue for countries with emerging and developing economies, like Chile, where ecosystem services are becoming increasingly vulnerable as demand increase and environment degrade is the generation of scientific information in order to support political decisions on development of environmental relevant projects. Such information can arise from extensive and time consuming centralized monitoring programs, but also complementarily from application modelling tools. Typically, mesoscale watersheds in the Southern Hemisphere represent a challenging management problematic: development of land use planning instruments considering the conservation of the native forest and the water availability for economic activities, recreation and human consumption.

Tendencies and extent of water yield affected by land use patterns depends on the particular study case. Land use changes modify interception and infiltration affecting surface runoff and groundwater flows (Sahin and Hall, 1996; Costa et al., 2003; Foley et al., 2005). Thus, combined with other biogeophysical properties of the land such as texture, relief, and soil types, land use controls the availability of water for its different uses e.g. irrigation and drinking water (Postel et al., 1996; Vitousek et al., 1997; Bronstert et al., 2002; Naef et al., 2003).

Land use changes might be modelled using economic, social and ecologic factors (Klocking et al., 2003). Heuristic rules defined by experts (Klocking and Haberlandt, 2002) present a lack between land use change and driving forces (Veldkamp and Lambin, 2001; Verburg et al., 2002). Statistical models (e.g. logistic regression model) improve the understanding of spatial patterns of the land use change (Veldkamp and Lambin, 2001).

Published by Copernicus Publications on behalf of the European Geosciences Union. 


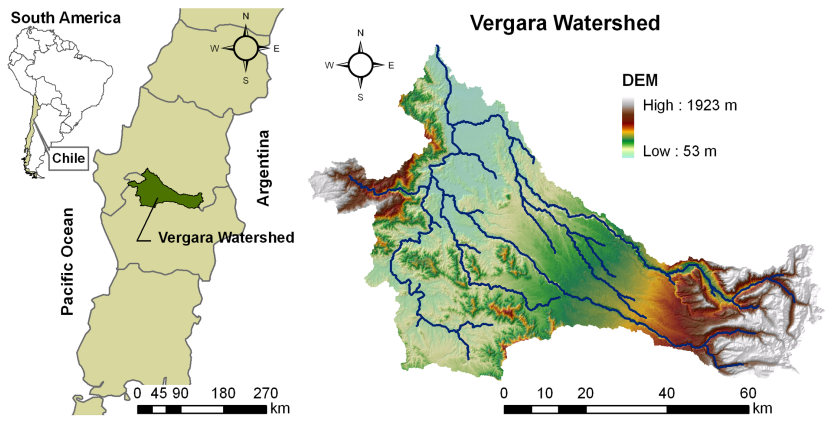

Fig. 1. Location of the Vergara watershed and DEM.

The processes dominating watershed hydrological response differ at various spatial scales. In micro-scale catchments (smaller than ca. $1 \mathrm{~km}^{2}$ ) response to rainfall is dominated mainly by the runoff generating processes at the hill slopes and the near-stream areas (Anderson and Burt, 1990; Montgomery and Buffington1997). In macro-scale watersheds (larger than $10^{4} \mathrm{~km}^{2}$ ) spatio-temporal distribution of precipitation, drainage pattern and runoff control to a considerable extend the response behaviour (Uhlenbrook et al., 2004). Heterogeneous land use in large watershed introduces additional complexities for modelling the water balance (Wilk et al., 2001). Klöcking and Hamberlandt (2002) stated that land use changes affect the hydrologic response of large watershed at the subbasin scale, and thus the interaction between the different subbasins plays a key role in the behaviour of the watershed. Even when the hydrologic response of small watersheds $\left(<10 \mathrm{~km}^{2}\right)$ has been extensively documented in previous studies (Bosch and Hewlett, 1982; Sahin and Hall, 1996; Stednick, 1996; Brown et al., 2005), and the response to land use changes of large scale basins have been documented for the Northern Hemisphere (Thanapakpawin et al., 2007; Hejazi and Moglen, 2008; Breuer and Huisman, 2009; van Roosmalen et al., 2009) a lack of studies on the response of mesoscale basins located in the Southern Hemisphere is detected (Costa et al., 2003; Croke et al., 2004).

The relationships between the different components of the hydrological cycle and their sensitivity to changes in land uses can be quantified applying physicaly based hydrologic models (Lahmer et al., 2001; Fohrer et al., 2001; Klocking et al., 2002; Eckhardt et al., 2003; Ott and Uhlenbrook, 2004). In particular, SWAT (Neitsch et al., 2002) allows the computation of hydrologic flows for long term analysis following a semi-distributed approach (Arnold et al., 1998; Fohrer et al., 2001, 2005; Arnold and Fohrer, 2005). Applications of SWAT for modelling watersheds located in the Northern Hemisphere have derived in well known recommended ranges of the involved parameters (Arnold et al., 1995; Arnold and Allen, 1999; Fontaine et al., 2002; Liu et al., 2002; Kannan et al., 2003; Van Liew et al., 2005; Muleta and Nicklow, 2005). For central Chile, Peña et al. (1985)

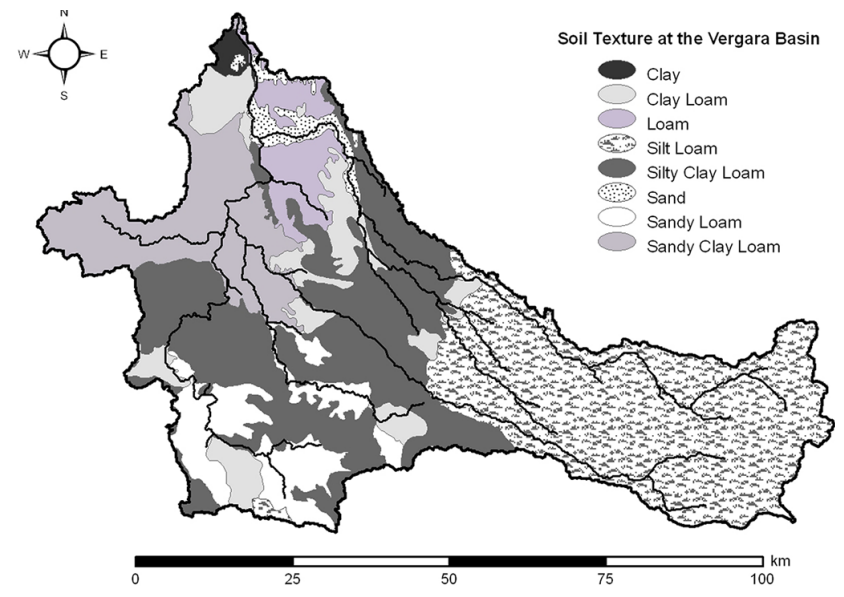

Fig. 2. Soil types in the Vergara watershed.

and Escobar and Vidal (1992) made some considerations on previous recommended ranges for the particular study cases.

In this contribution the hydrologic response of the Vergara watershed to different probable future scenarios of land use was analysed through the annual mean discharge applying the physically based hydrologic model SWAT. The land use scenarios were generated using heuristic rules and the logistic regression model. First, the study area, available hydrometeorological records, and methods for land use analysis and hydrologic flows computation are presented. Next, the model sensitivity analysis, calibration and validation are presented. Finally, simulation results are analysed in order to suggest adequate guidelines for watershed management.

\section{Study area}

The Vergara watershed $\left(4340 \mathrm{~km}^{2}\right)$ is located between the parallels $37^{\circ} 29^{\prime}$ and $38^{\circ} 14^{\prime}$ and $71^{\circ} 36^{\prime}-73^{\circ} 20^{\prime}$. The river is $154 \mathrm{~km}$ long and emerges at an elevation of about $1900 \mathrm{~m}$ a.s.l. It flows into the Biobío river near the city of Nacimiento at an altitude of $200 \mathrm{~m}$ a.s.l. Its Strahler's stream order is 4 . The climate in the watershed is temperate mediterranean, with a dry season of 5 months (November-March), and a wet season of approximately 3 months (May-July) during which more than $50 \%$ of the precipitation occurs. Ambient mean daily temperature ranges between $18^{\circ} \mathrm{C}$ in January and $8{ }^{\circ} \mathrm{C}$ in June, with an annual mean of $12.5^{\circ} \mathrm{C}$. The average annual precipitation is $1650 \mathrm{~mm}$. Recorded minimum and maximum mean daily discharges of the river close to the basin outlet, i.e. at Tijeral gauging station, are $0.81 \mathrm{~m}^{3} \mathrm{~s}^{-1}$ (24 January 2002) and $999 \mathrm{~m}^{3} \mathrm{~s}^{-1}$ (27 May 1984), respectively. Maximum and minimum mean monthly discharges occur during the months of July and February-March, respectively. Figure 1 shows the location of the basin with the drainage network and digital elevation model, DEM obtained 

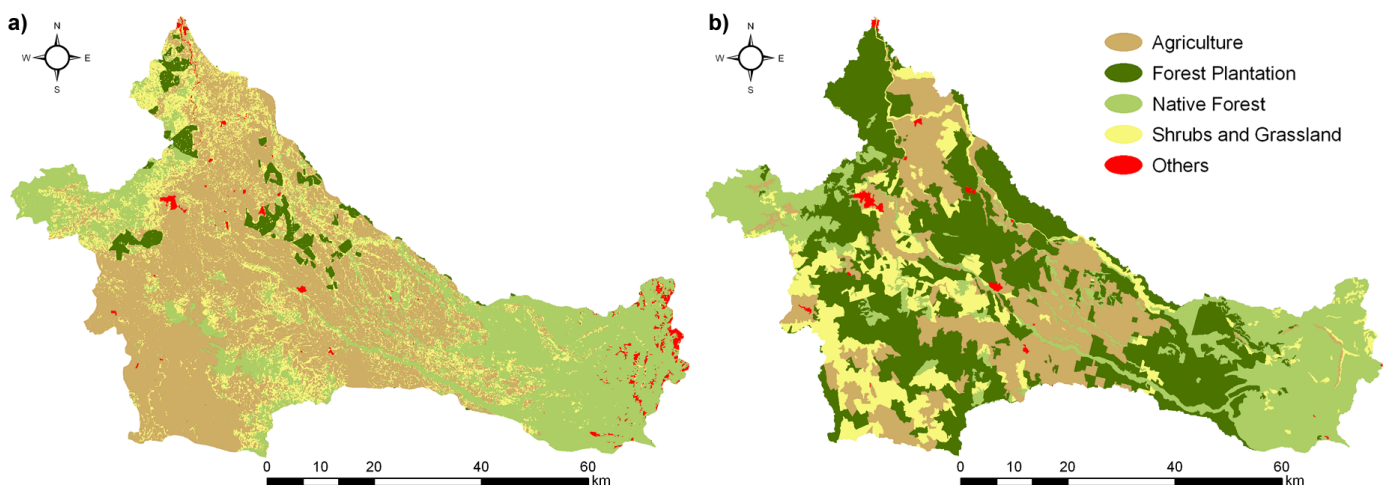

Fig. 3. Land cover in 1979 (left) and 1994 (right).

Table 1. Curve number and Manning's coeficient for the main land uses in the Vergara watershed.

\begin{tabular}{|c|c|c|c|c|c|c|}
\hline \multicolumn{2}{|c|}{ Parameter } & Description & $\begin{array}{l}\text { Forestry } \\
\text { plantation }\end{array}$ & $\begin{array}{l}\text { Native } \\
\text { forest }\end{array}$ & Agriculture & $\begin{array}{l}\text { Shrubs and } \\
\text { grassland }\end{array}$ \\
\hline \multirow{4}{*}{$\mathrm{CN} 2$} & A & Initial SCS CN II value, Soil Hydrologic Group A & 35 & 45 & 62 & 49 \\
\hline & B & Initial SCS CN II value, Soil Hydrologic Group B & 55 & 66 & 73 & 69 \\
\hline & $\mathrm{C}$ & Initial SCS CN II value, Soil Hydrologic Group C & 70 & 77 & 81 & 79 \\
\hline & $\mathrm{D}$ & Initial SCS CN II value, Soil Hydrologic Group D & 77 & 83 & 84 & 84 \\
\hline \multicolumn{2}{|c|}{ OV_N } & Manning's "n" value for overland flow. & 0.4 & 0.8 & 0.15 & 0.4 \\
\hline
\end{tabular}

from available images of the shuttle radar topography mission, SRTM DEM (final version).

\section{Data sets used}

\subsection{Soil types}

The GIS layer representing the different soils in the watershed was obtained from CIREN (1999a) and CIREN (1999b). The most common soils in the watershed are silt loam soils $(33 \%)$ originated from volcanic ash deposits, silty clay loam soils (29\%) developed from old volcanic ashes and sandy clay loam soils $(13 \%)$ with granitic origin and richness in quartz. Figure 2 shows the soil type distribution in the watershed.

\subsection{Land uses}

Land uses are classified according to the land cover database proposed by Neitsch et al. (2002) which includes the description of 97 different land uses. In the particular study case, all the observed land uses where found in the land cover database by Neitsch et al. (2002). Arising differences between (introduced) forest plantation and native forest are mainly the corresponding curve number and the Manning roughness coefficient for overland flow. Table 1 shows Curve Number and Manning's coefficient for the main land uses in the Vergara watershed. Note that as expected and according to the curve number method, forestry plantation consumes more water than native forest and native forest consumes more water than agriculture, while initial abstraction, i.e. retention, decreases with the curve number.

Figure 3 shows the land uses of the watershed for the years 1979 and 1994. In the year 1979 the main land use was agriculture covering a $47 \%$ of the watershed area, $31 \%$ was covered by native forest and $18 \%$ by scrubland. Remarkably, forest plantations covered a negligible area of the watershed, and were minimal compared to the other uses. Agriculture was the dominant land use in the lowest and middle part of the watershed, while at the upper part it was the native forest. In the year 1994 the major types of land uses were forestry plantations with $38 \%$, native forest with $21 \%$ and agriculture with $32 \%$ of the watershed area. In the lowest, middle and highest regions of the basin, the main land uses were agriculture, forestry plantations, and native forest, respectively. Main economic activities in the watershed are linked with the exploitation of natural resources and development of forest industry, mainly pulp and paper mills. Historically, native forest exploitation was followed by the farming activity which in turn has been gradually replaced by forestation with exotic species, mainly Pinus radiata and Eucaliptus globulus. Table 2 indicates the area covered by each land use and the percentage respect to the watershed area for the years 1979 and 1994. 
Table 2. Changes in land cover between 1979 and 1994.

\begin{tabular}{lcccccc}
\hline Land cover & $\begin{array}{c}\text { Covered area } \\
\text { in } 1979(\text { ha) }\end{array}$ & $\begin{array}{c}\text { Portion of the } \\
\text { basin }(\%)\end{array}$ & $\begin{array}{c}\text { Covered area } \\
\text { in } 1994(\text { ha) }\end{array}$ & $\begin{array}{c}\text { Portion of the } \\
\text { basin }(\%)\end{array}$ & $\begin{array}{c}\text { Land use } \\
\text { change (ha) }\end{array}$ & $\begin{array}{c}\text { Change in land } \\
\text { cover }(\%)\end{array}$ \\
\hline Native forest & 133.096 & 31 & 92.533 & 21 & -40.563 & -30 \\
Scrubland & 77.532 & 18 & 29.897 & 7 & -47.635 & -61 \\
Steppe & 3.157 & 1 & 3.157 & 1 & 0 & 0 \\
Forestry plantation & 15.129 & 3 & 164.587 & 38 & 149.458 & 988 \\
Agriculture & 203.055 & 47 & 140.945 & 32 & -62.110 & -3 \\
Urban areas & 1.071 & 0 & 1.992 & 0 & 921 & 86 \\
Bare soil & 108 & 0 & 209 & 0 & 101 & 94 \\
Water bodies & 814 & 0 & 643 & 0 & -171 & -21 \\
Total & 433.963 & 100 & 433.963 & 100 & & \\
\hline
\end{tabular}

Table 3. Land use transition matrix for the years 1979 and 1994. Values in [ha].

\begin{tabular}{|c|c|c|c|c|c|c|c|c|c|c|}
\hline \multicolumn{11}{|c|}{1979} \\
\hline & & $\begin{array}{l}\text { Native } \\
\text { forest }\end{array}$ & Scrubland & Steppe & $\begin{array}{l}\text { Forestry } \\
\text { plantation }\end{array}$ & Agriculture & $\begin{array}{l}\text { Water } \\
\text { bodies }\end{array}$ & $\begin{array}{c}\text { Bare } \\
\text { soil }\end{array}$ & $\begin{array}{c}\text { Urban } \\
\text { areas }\end{array}$ & Total \\
\hline \multirow{9}{*}{1994} & Native forest & 92533 & 0 & 0 & 0 & 0 & 0 & 0 & 0 & 92533 \\
\hline & Scrubland & 6836 & 14228 & 0 & 306 & 8459 & 15 & 53 & 0 & 29897 \\
\hline & Steppe & 0 & 0 & 3157 & 0 & 0 & 0 & 0 & 0 & 3157 \\
\hline & Forestry plantation & 30428 & 38550 & 0 & 14817 & 80706 & 80 & 6 & 0 & 164587 \\
\hline & Agriculture & 3202 & 24453 & 0 & 6 & 113189 & 72 & 22 & 0 & 140945 \\
\hline & Water bodies & 0 & 0 & 0 & 0 & 0 & 643 & 0 & 0 & 643 \\
\hline & Bare soil & 31 & 80 & 0 & 0 & 71 & 3 & 24 & 0 & 209 \\
\hline & Urban areas & 67 & 222 & 0 & 0 & 631 & 0 & 1 & 1071 & 1992 \\
\hline & Total & 133096 & 77532 & 3157 & 15129 & 203055 & 814 & 108 & 1071 & 433963 \\
\hline
\end{tabular}

Main land cover changes in the watershed observed between 1979 and 1994 are the increase in forestry plantations and the decrease of scrubland, native forest and agriculture. In the year 1994, the areas covered by forest plantations increased 10 times with respect to those observed in 1979, mainly occupying previous agriculture land (54\% of the total new forest plantation), and areas with shrubs and native forest $(56 \%)$. The shrub coverage diminished by $50 \%$, of which one half was occupied by forest plantations and one half by agricultural production. The native forest diminished in 40000 ha, i.e. the $30 \%$ of the area covered in 1979 . Of this, $75 \%$ was replaced by forest plantations. Table 3 shows the landuse transition matrix, i.e. the changes of landuses for different years. The total of each column and row indicates the area of the land covers for the years 1979 and 1994, respectively. Column values indicate the land cover changes occurred between 1979 and 1994 (e.g. 30428 ha of native forest for a total of 133096 ha were converted to forest plantations). The values of the diagonal indicate the area that remained the same during the period (e.g. 92533 ha of native forest from a total of 133096 ha were maintained during the period 1979-1994).

\subsection{Hydrological records}

Figure 4 shows the location of the 22 existing hydrometeorologic stations located in or close to the Vergara watershed and the period of recorded series of precipitation, river discharges and ambient temperature. The point meteorological measurements were spatialized in order to generate precipitation data for each subbasin. The methodology incorporated in ArcSWAT was followed, i.e. rainfall data for runoff calculation were obtained from the precipitation station located closest to the subbasin centroid. Alternativelly, Thiessen polygons could be applied for this purpouse. For the present study case, no significant differences in resulting precipitations arised because neglegible rainfall gradients between meterological stations forming each Thiessen polygon were observed in the lower and middle part of the watershed. In the upper part Thiessen polygons would underestimate real precipitation, weighting measured values at the central valley and the Andean Mountain Range. Figure 5 shows the subbasins and the precipitation stations used for assignment of precipitation data. 
Table 4. Mean monthly discharges $\left[\mathrm{m}^{3} \mathrm{~s}^{-1}\right]$ at the different control points in the Vergara basin (1977-2002).

\begin{tabular}{lccccc}
\hline & Tijeral & Rehue $^{\mathrm{a}}$ & Renaico $^{\mathrm{b}}$ & Mininco & Malleco \\
\hline Maximum mean monthly discharge & 162.37 (July) & 17.17 (July) & $88.75($ July) & 40.02 (July) & 59.17 (July) \\
Minimum mean monthly discharge & 7.39 (February) & 0.22 (February) & 6.89 (March) & 2.16 (February) & 3.81 (March) \\
Mean annual discharge & 57.52 & 6.07 & 42.63 & 15.81 & 26.58 \\
\hline
\end{tabular}

${ }^{a}$ Measured discharge data since July $1997 .^{\text {b }}$ Measured discharge data since July 1982.
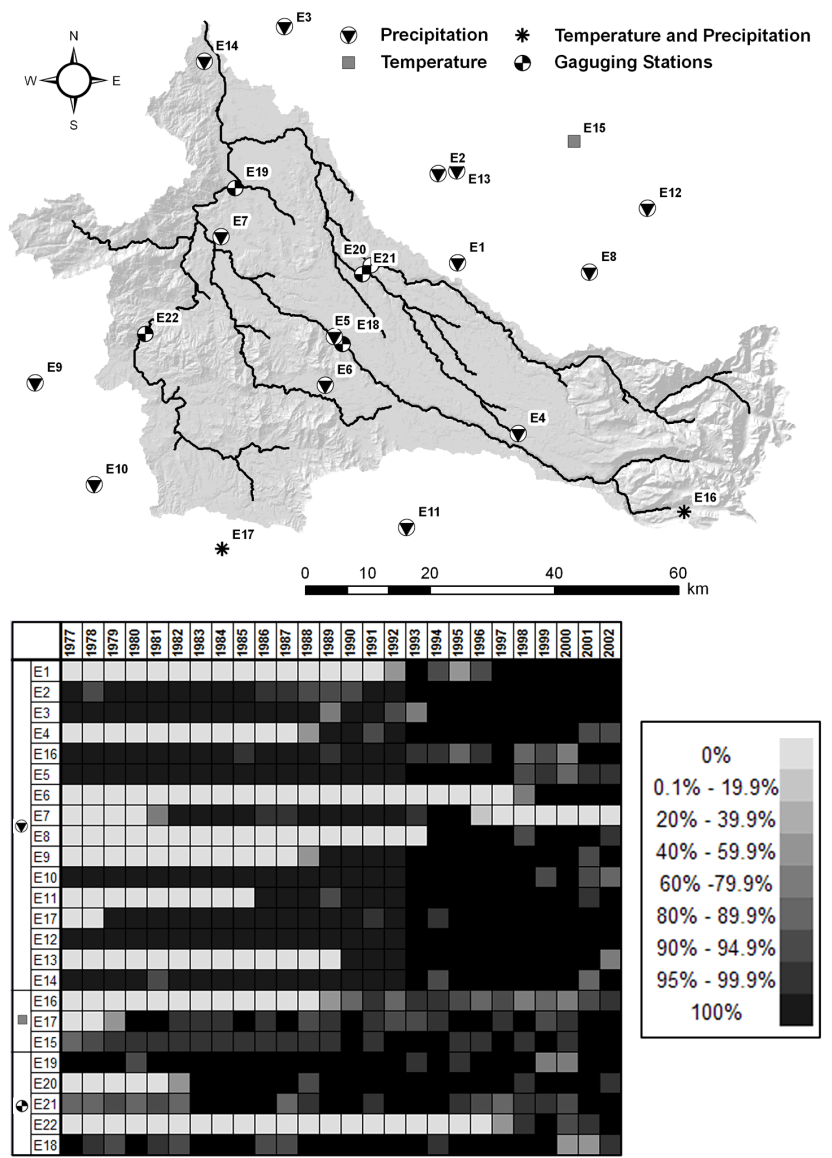

Fig. 4. Location of hydrometeorologic stations and available record periods.

Figure 6 shows the location of the five gauging stations and corresponding drainage area.

Figure 7 shows the existing hydrographs for the period 1977-2002 recorded at Tijeral, Rehue, Mininco, Renaico, and Malleco gauging stations.

Table 4 indicates maximum, minimum and mean monthly discharges for all gauging stations.

Observed discharges diminish from Tijeral to Renaico, Malleco and Mininco. Rehue is a nested basin of Tijeral, presenting the smallest discharges.

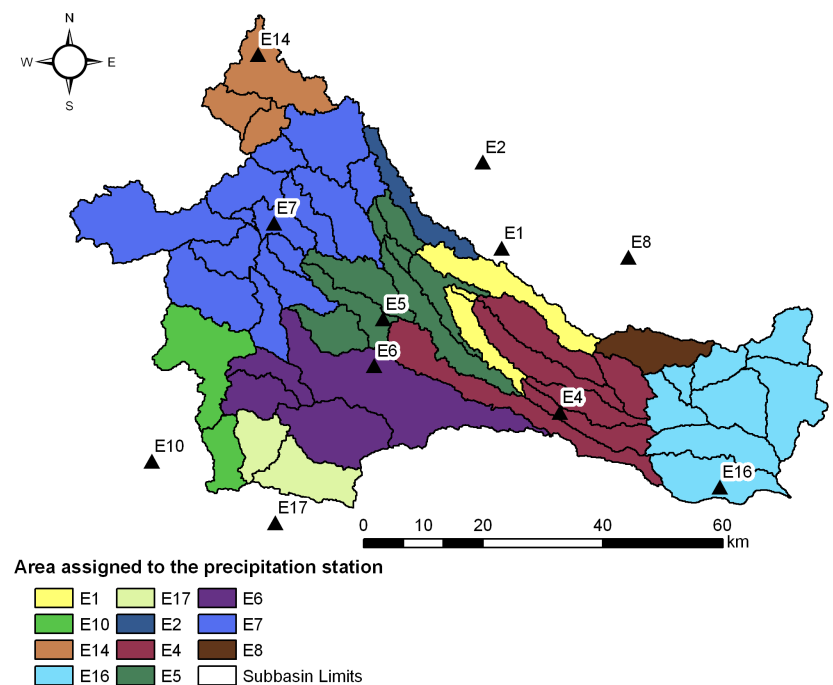

Fig. 5. Gauging stations in the watershed.

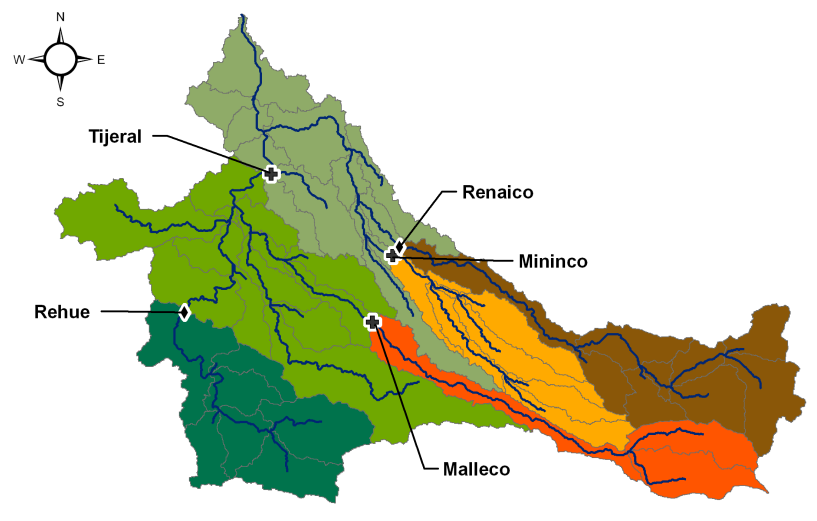

- Gauging Stations only 1994-2002

+ Gauging Stations 1977-1982 and 1994-2002

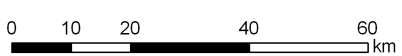

Fig. 6. Gauging stations in the watershed.

\section{Generation of probable land use scenarios}

Probable land use scenarios were generated following two approaches based on heuristic rules and using the logistic regression model. The heuristic rules are based on assumptions of land use restrictions for limitation of a watershed 
Table 5. Results of the adjustment of the logistic regression for forest plantation sprawl $(* *=p<0.01)$.

\begin{tabular}{lrrrc}
\hline Variables & $\beta(i)$ & Standard error & Wald $^{\mathrm{a}}$ & $p$ \\
\hline Elevation & -0.00193 & 0.000096 & 404.52 & $* *$ \\
Slope & -0.00653 & 0.001926 & 11.48 & $* *$ \\
Distance from native forest & -0.00097 & 0.000053 & 341.39 & $* *$ \\
Distance of forest plantations & -0.00005 & 0.000003 & 271.19 & $* *$ \\
Distance from urban areas & 0.00006 & 0.000003 & 314.29 & $* *$ \\
Size ownership & -0.00001 & 0.000001 & 66.08 & $* *$ \\
Constant $\left(\beta_{0}\right)$ & 1.13899 & 0.049907 & 520.85 & $* *$ \\
\hline
\end{tabular}

${ }^{a}$ Wald test is used to test the statistical significance of each coefficient $(b)$ in the model

Table 6. Ranking of the four most sensitive parameters in Tijeral, Rehue, Renaico, Mininco and Malleco.

\begin{tabular}{|c|c|c|c|c|c|c|}
\hline Parameter & Description & Tijeral & Rehue & Mininco & Renaico & Malleco \\
\hline GWQMN & Threshold water depth in the shallow aquifer for flow & 2 & 3 & 2 & 4 & 2 \\
\hline GW_REVAP & Groundwater revap coefficient & & 4 & & & \\
\hline $\mathrm{CN} 2$ & Initial SCS CN II value & 1 & 2 & 1 & 1 & 1 \\
\hline SOL_AWC & Available water capacity & 3 & & 4 & 2 & 3 \\
\hline rchrg_dp & Deep aquifer percolation fraction & 4 & 1 & 3 & 3 & 4 \\
\hline
\end{tabular}

portion that could be covered by a certain land use. Generated scenarios with this approach simulated the existence of laws for conservation of native forest, causing that (1) the actual native forest coverage does not change and the rest of the watershed become covered by introduced forest species, and the inexistency of adequate land use planning instruments allowed a deliberated land use in the watershed causing that (2) the native forest coverage does not change, but the rest of the watershed becomes completely covered by agriculture land. The regression model was based on observed information available in the satellite images of 1979 and 1994 for the prediction of patterns of forest expansion, deforestation advancing, and substitution of native forest generating a scenario where (3) observed patterns of land use changes between 1979 and 1994 continue with the same tendency. Scenario 3 was obtained using a set of prediction variables such as elevation, slope, distance from native forest, distance of forest plantations, distance from urban areas and size ownership. To quantify the relationship between land cover changes and its causal factors, the maps of 1979-1994 were sprawl and the results were related to a set of predictor variables (change and non change) that were selected based on current knowledge of landuse change process in the Vergara watershed as presented in Echeverría et al. (2006, 2007), Altamirano et al. (2007) and Aguayo et al. (2009). Table 5 shows these variables. An appropriate binary response variable was constructed from the observed forest expansion pattern and a logistic regression model was used to predict the probability of land cover change depending on the various predictor variables (Eq. 1; Table 5).
$P(y=1 \mid x)=\frac{e^{\beta_{0}+\sum_{i=1}^{n} \beta_{i} x_{i}}}{1+e^{\beta_{0}+\sum_{i=1}^{n} \beta_{i} x_{i}}}$

where, $P(y=1 \mid x)$ is the Probability, $x_{i}$ are the different variables, $\beta_{0}$ is a Constant, $\beta_{i}$ are the variable coefficients and $\mathrm{n}$ number of variables.

\section{Soil and water assessment tool, SWAT}

The physically based hydrologic model SWAT computes runoff, infiltration, percolation and groundwater flows at a daily scale for long-term response analysis. In the model, the watershed is divided in subbasins, which for semi-distributed computation of flows are again internally subdivided into hydrologic response units with relative homogeneous topography, soil type, and land use. For computations, SWAT requires a digital elevation model, soil type and land use maps as well as precipitation and ambient temperature.

Surface runoff was computed with the curve number method. Several previous studies show the applicability of the SCS CN approach for the study region. The SCS CN method has been extensively tested and modified in order to represent local conditions. For details, please refer to Iroumé et al. (1999), Saavedra and Stowhas, (2003), Stowhas (2003) and Pizarro et al. (2006).

A rainfall-runoff model based on the curve number method is very sensitive against $\mathrm{CN}$ values, which control the portion of rainfall that is converted to runoff. The $\mathrm{CN}$ value depends on land cover, soil type, slope and antecedent 
Table 7. Sensitive parameters obtained in the referred studies.

\begin{tabular}{lll}
\hline Author & Country & Most sensitive parameters \\
\hline Kannan et al. (2007) & UK & AWC, Sol_K, ESCO, GWQMN and CN2 \\
Spruill et al. (2000) & USA & Sol_K, Alpha_Bf \\
Arnold et al. (2000) & USA & CN2, Sol_Awc, ESCO \\
Holvoet et al. (2005) & Belgium & CN2, surlag, rchrg_dp, GWQMN \\
Van Griensven et al. (2006) & USA & CN2, Gwqmn, Alpha_Bf, Sol_Awc, Sol_z, Smfmx, ESCO, CANMX \\
White and Chaubey (2005) & USA & CN2, ESCO, Sol_AWC, \\
\hline
\end{tabular}
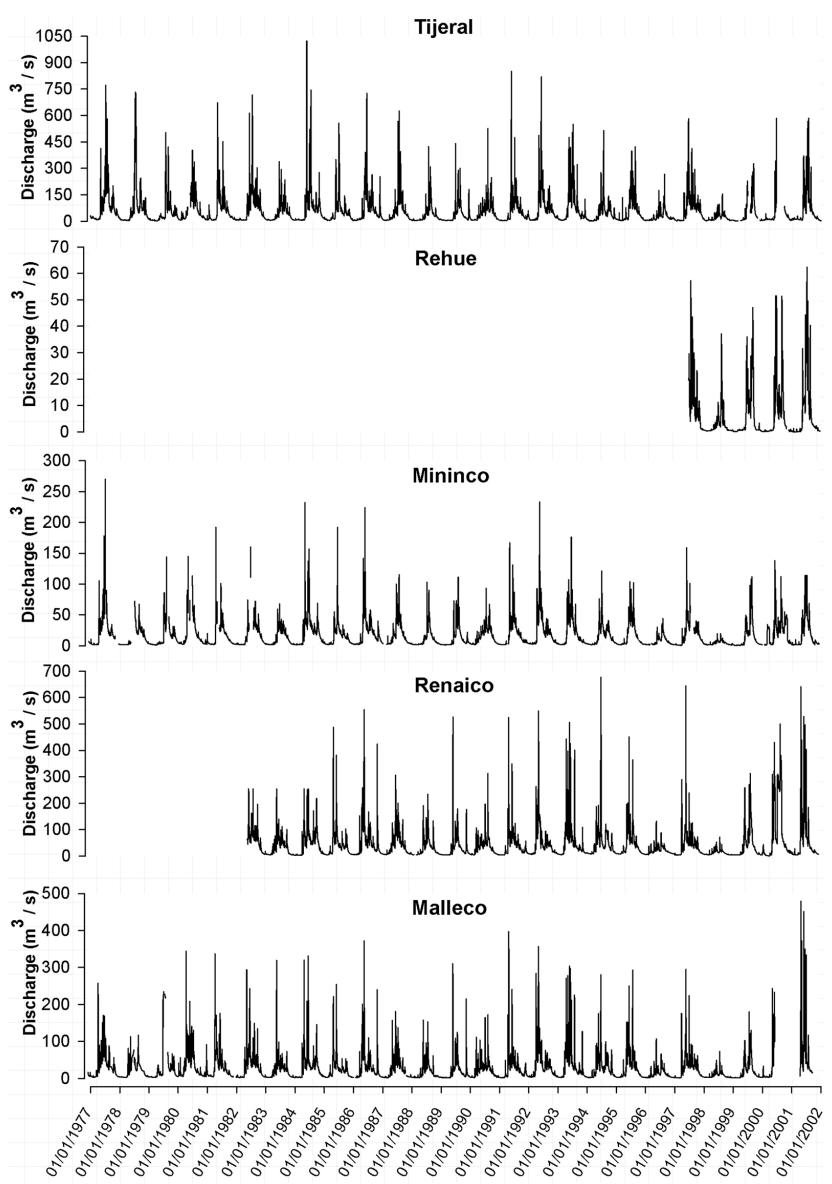

Fig. 7. Hydrographs based on daily mean discharges for the period 1977-2002 recorded at Tijeral, Rehue, Mininco, Renaico, and Malleco gaugin stations.

soil moisture. Water is routed using the kinematic wave approach, using Manning's relation for estimation of the runoff speed.

SWAT includes three different methods for computation of evaporation/evapotranspiration, namely: Penman-Monteith, Priestley-Taylor and Hargreaves. As there are no records of wind speed, relative humidity and solar radiation in the basin, but maximum and minimum temperatures are available from existent meteorological stations the Hargreaves method was employed. The Hargreaves method has shown good results in different type of climates (Jensen et al., 1990; Allen et al., 1998; Antonioletti et al., 1998; Droogers et al., 2002; Saghravani et al., 2009). Moreover, Jensen et al. (1990) compared 20 different evapotranspiration methods against lysimeter data. Of all methods that required only air temperature the Hargreaves method showed the best results.

SWAT split groundwater into two aquifer systems: a shallow, unconfined aquifer which contributes return flow to streams within the subbasin, and a deep, confined aquifer which contributes return flow to streams outside the subbasin (Arnold et al., 1993). Water percolation under the root zone is partitioned in two fractions - each fraction becomes recharge contributing to one of both aquifers. In addition to return flow, water stored in the shallow aquifer may replenish moisture in the soil profile in very dry conditions or be directly removed by plants. The model considers transfer from the shallow to the deep aquifer. In snow accumulation and melt modelling each sub-basin generated in SWAT is divided into 10 elevation bands in order to incorporate temperature and precipitation variations with respect to altitude (Hartman et al., 1999). For each sub-basin, different lapse rates for precipitation plaps $\left(\mathrm{mm} \mathrm{H}_{2} \mathrm{O} \mathrm{km}^{-1}\right)$ and temperature tlaps $\left({ }^{\circ} \mathrm{C} \mathrm{km}^{-1}\right)$ were defined, which were then used to account for the differences in precipitation and temperature between these elevation bands.

The Latin Hypercube Sampling/One-at-a-Time, LH-OAT analysis incorporated in SWAT2005 (Van Griensven et al., 2006) allows the identification and ranking of the model's most sensitive parameters. OAT (Morris, 1991) design integrates a local to a global sensitivity method. LH-OAT sensitivity analysis assures that all the parameter range has been sampled and changes in the output of each model run is uniquely attributed to the input change. The automated calibration procedure Parameter Solution Method (PARASOL; Van Griensven et al., 2003) was used for calibration of the most sensitive parameters. This procedure used the Shuffle Complex Evolution Algorithm as optimization method, which is a global search algorithm for the minimization of a single function for up to 16 parameters (Duan et al., 1992). It combines the direct search method of the Simplex procedure 
a)
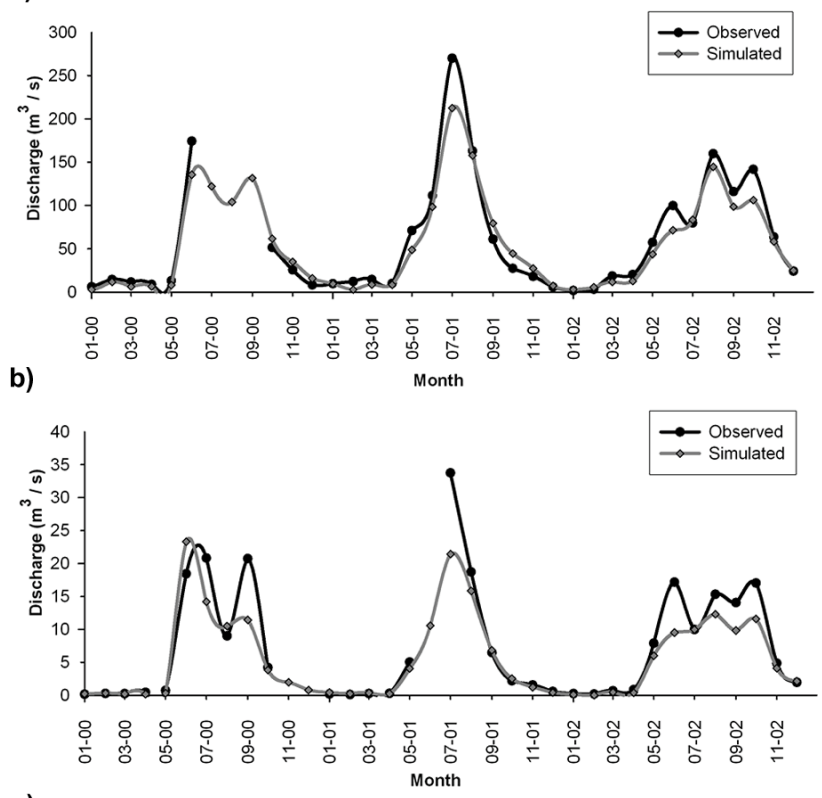

c)
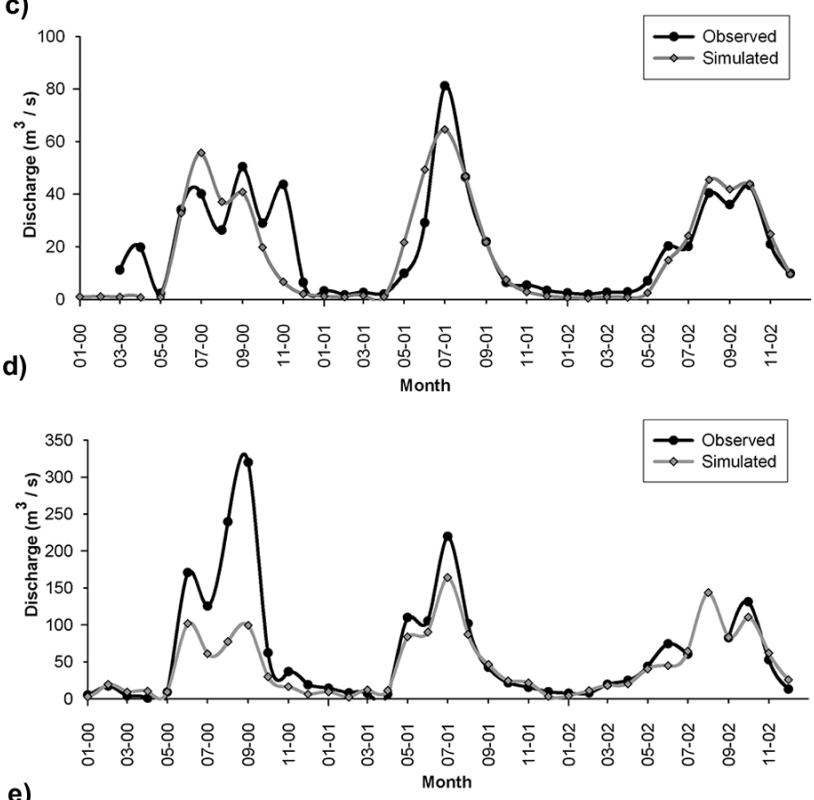

e)

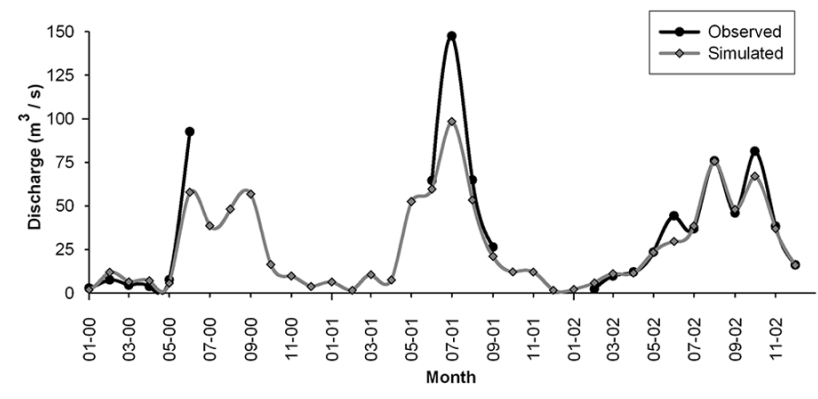

Fig. 8. Observed and simulated mean monthly discharges during years 2000-2002 at Tijeral (a), Rehue (b), Mininco (c), Renaico (d) and Malleco (e). a)

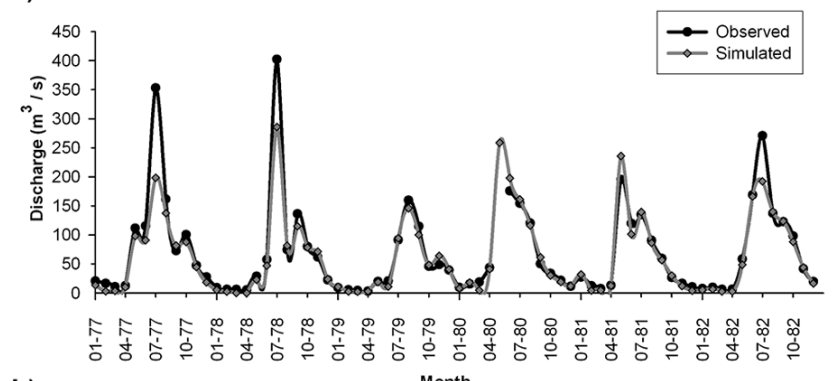

b)
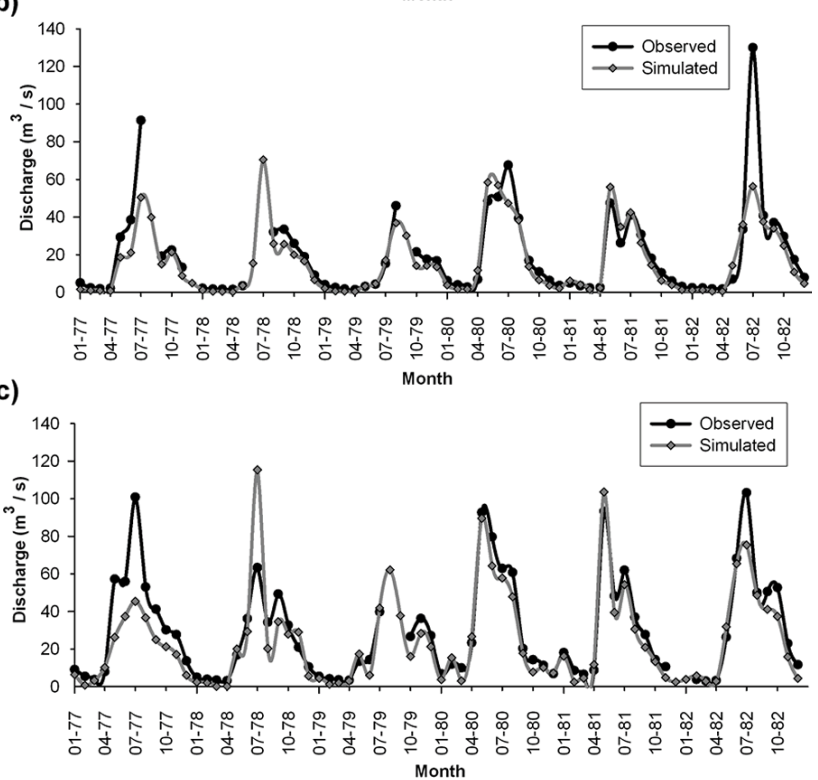

Fig. 9. Observed and simulated mean monthly discharges for the years 1977-1982 at the gauge stations Tijeral (a), Mininco (b) and Malleco (c).

with the concept of a controlled random search, a systematic evolution of points in the direction of global improvement, competitive evolution and the concept of complex shuffling (Van Griensven et al., 2006). To obtain the optimum solution the sum of the squares of the residuals (SSQ) was used. Upper and lower parameter value bounds used for automated calibration were established based on recommendations made by (Van Liew et al., 2005) and based on own experience from previous work on the Biobío basin (Stehr et al., 2008, 2009).

\section{Results and discussion}

For flow computation 51 subbasins with 272 hydrologic response units were defined. For calibration, the time series of years 2000-2002 were used. A novel validation process of the calibrated model was conducted. Performance of the model was evaluated for two periods with different dominant land uses, namely period 1977-1982 with the land use map of 1979, and period 1994-1999 with the land use map 
a)

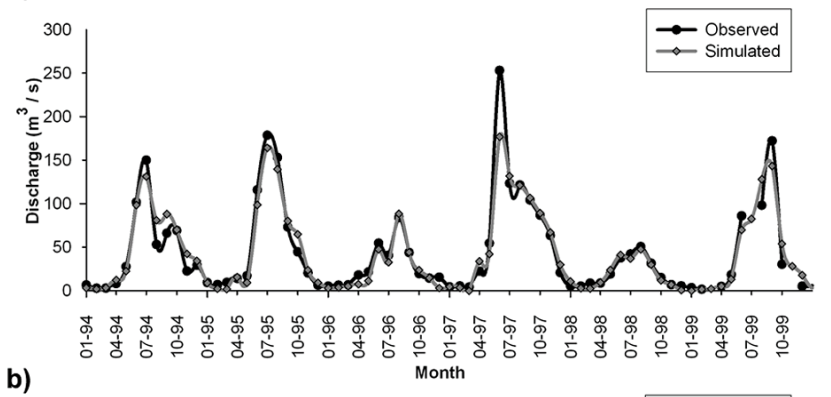

b)

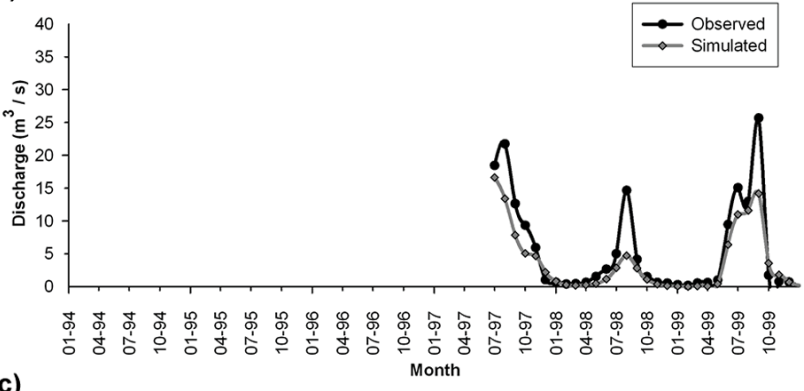

c)

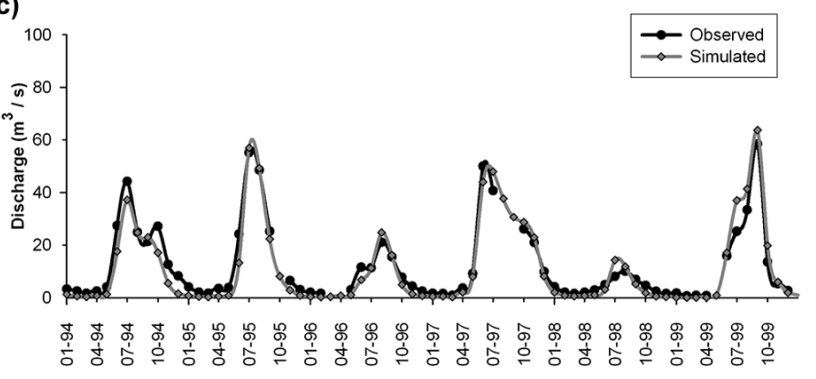

d)

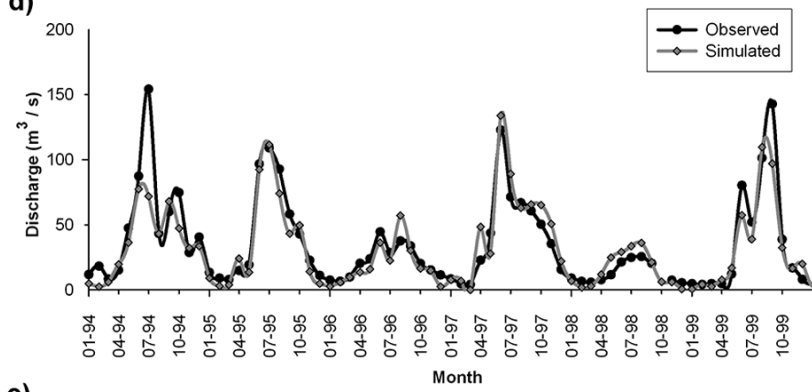

e)

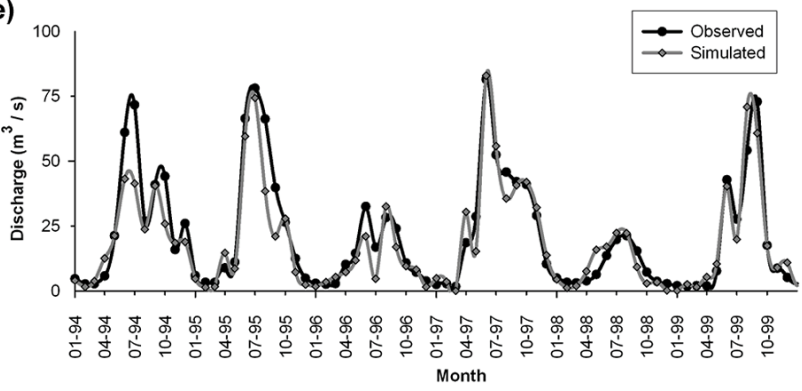

Fig. 10. Observed and simulated monthly discharges for the years 1994-1999 at gauge stations Tijeral (a), Rehue (b), Mininco (c), Renaico (d) and Malleco (e).
Table 8. RMS error, absolute error, efficiency, determination coefficient and percentage of Bias calculated for the period 2000-2002 after calibration.

\begin{tabular}{lccccc}
\hline & Tijeral & Rehue & Mininco & Renaico & Malleco \\
\hline RRMSE & 0.30 & 0.51 & 0.50 & 0.82 & 0.37 \\
ABSERR & 11.64 & 1.99 & 6.31 & 24.16 & 7.52 \\
EF & 0.93 & 0.82 & 0.72 & 0.54 & 0.85 \\
$R^{2}$ & 0.96 & 0.88 & 0.76 & 0.71 & 0.93 \\
PBIAS & 11.78 & 21.35 & 8.32 & 32.04 & 14.94 \\
\hline
\end{tabular}

of 1994 , in order to check if the model is able to adequately reproduce the catchment hydrology under different land use scenarios, i.e. if model performance significantly varies with land use change. Computed and measured monthly discharges were compared at Tijeral, Rehue, Renaico, Mininco and Malleco and model performance was evaluated through RMS error, absolute error, Nash-Sutcliffe's efficiency, determination coefficient, and percent bias.

\subsection{Sensitivity analysis}

Table 6 shows the ranking of the four most sensitive parameters obtained with LH-OAT analysis for basin Tijeral, Rehue, Renaico and Mininco for years 2000-2002. The subbasin Malleco was not analysed, because there are insufficient discharge records between the years 2000-2002. As Malleco is a subbasin of Tijeral, identical parameter values were considered for both.

The most sensitive parameter is the CN2 value. Other sensitive parameters are Gwqmn, Sol_Awc and rchrg_dp. This results are in agreement with those by Arnold et al. (2000), Spruill et al. (2000), White and Chaubey (2005), Holvoet et al. (2005), Van Griensven et al. (2006), and Kannan et al. (2007). Table 7 shows the sensitive parameters obtained in the referred studies.

According to Table 7 a similar behaviour of SWAT for applications in the basins located in south-central Chile, i.e. Vergara and subbasins, to that reported for watersheds located in the Northern Hemisphere is observed.

\subsection{Calibration of the model}

The most sensitive parameters of the model were calibrated for the years 2000-2002 in order to reproduce the observed discharges at the available gauge stations: Tijeral, Rehue, Renaico, Mininco and Malleco using the parameter solution method PARASOL. Figure 8 shows the observed and computed discharges for the years 2000-2002 after calibration.

The model satisfactorily reproduced the order of magnitude of the observed discharges, and their changes tendency in time. Nevertheless, the model underestimates peak 
Table 9. Parameters involved in the computation of surface runoff in the Vergara watershed.

\begin{tabular}{|c|c|c|c|c|c|}
\hline Parameter & Description & Units & Recommended range & Reference & $\begin{array}{l}\text { Range after } \\
\text { PARASOL }\end{array}$ \\
\hline ALPHA_BF & $\begin{array}{l}\text { Baseflow recession con- } \\
\text { stant }\end{array}$ & & $0.01-0.05$ & $\begin{array}{l}\text { Arnold et al. (1995); Arnold } \\
\text { and Allen (1999) }\end{array}$ & $0.01-0.05$ \\
\hline $\mathrm{CN} 2$ & Initial SCS CN II value & & $39-68$ & Muleta and Nicklow (2005) & $35-92$ \\
\hline EPCO & $\begin{array}{l}\text { Plant uptake compensation } \\
\text { factor }\end{array}$ & & $0.001-1$ & Muleta and Nicklow (2005) & 1 \\
\hline ESCO & $\begin{array}{l}\text { Soil evaporation compensa- } \\
\text { tion factor }\end{array}$ & & $0.13-0.95$ & Van Liew et al. (2005) & $0.1-0.95$ \\
\hline GW_DELAY & $\begin{array}{l}\text { Delay time for aquifer } \\
\text { recharge }\end{array}$ & days & $0-380$ & Van Liew et al. (2005) & 31 \\
\hline GW_REVAP & $\begin{array}{l}\text { Groundwater revap coeffi- } \\
\text { cient }\end{array}$ & & $0.02-0.2$ & Van Liew et al. (2005) & 0.02 \\
\hline GWQMN & $\begin{array}{l}\text { Threshold water depth in } \\
\text { the shallow aquifer for base } \\
\text { flow }\end{array}$ & $\mathrm{mm}$ & $0-3560$ & Van Liew et al. (2005) & $0-200 \mathrm{~mm}$ \\
\hline REVAPMN & $\begin{array}{l}\text { Threshold water depth in } \\
\text { the shallow aquifer for re- } \\
\text { vap }\end{array}$ & $\mathrm{mm}$ & $0-100$ & Muleta and Nicklow (2005) & 1 \\
\hline RCHRG_DP & $\begin{array}{l}\text { Deep aquifer percolation } \\
\text { fraction }\end{array}$ & & $0.01-0.75$ & Muleta and Nicklow (2005) & $0.05-0.1$ \\
\hline SFTMP & Snowfall temperature & ${ }^{\circ} \mathrm{C}$ & 1.0 & Escobar and Vidal (1992) & 1.0 \\
\hline SMFMN & $\begin{array}{l}\text { South Hemisphere: Max- } \\
\text { imum melt rate for snow } \\
\text { during the year (occurs on } \\
\text { winter solstice) }\end{array}$ & $\mathrm{mm} /\left({ }^{\circ} \mathrm{C}\right.$ day $)$ & 6.5 & Escobar and Vidal (1992) & 6.5 \\
\hline SMFMX & $\begin{array}{l}\text { South Hemisphere: Min- } \\
\text { imum melt rate for snow } \\
\text { during year (occurs on sum- } \\
\text { mer solstice) }\end{array}$ & $\mathrm{mm} /\left({ }^{\circ} \mathrm{C}\right.$ day $)$ & 3.5 & Escobar and Vidal (1992) & 3.5 \\
\hline SMTMP & $\begin{array}{l}\text { Snow melt base tempera- } \\
\text { ture }\end{array}$ & ${ }^{\circ} \mathrm{C}$ & $-2-20$ & Muleta and Nicklow (2005) & 0.5 \\
\hline SOL_AWC & Available water capacity & $\mathrm{mm} \mathrm{H}_{2} \mathrm{O} / \mathrm{mm}$ soil & $0.08-0.16$ & Kannan et al. (2003) & $0.2-0.55$ \\
\hline SOL_K & $\begin{array}{l}\text { Saturated hydraulic con- } \\
\text { ductivity }\end{array}$ & $\mathrm{mm} / \mathrm{h}$ & 0-208 & Liu et al. (2002) & $1.5-208$ \\
\hline TIMP & $\begin{array}{l}\text { Snow pack temperature lag } \\
\text { factor }\end{array}$ & & $0.5-1$ & Muleta and Nicklow (2005) & 1 \\
\hline PLAPS & Precipitation lapse rate & $\mathrm{mm} / \mathrm{km}$ & 0.5 & Fontaine et al. (2002) & 0 \\
\hline TLAPS & Temperature lapse rate & ${ }^{\circ} \mathrm{C} \mathrm{km}^{-1}$ & $-7.5--6.5$ & Peña et al. (1985) & -6 \\
\hline $\mathrm{OV} \_\mathrm{N}$ & $\begin{array}{l}\text { Manning's " } n \text { " value for } \\
\text { overland flow }\end{array}$ & & $0.2-0.8$ & Muleta and Nicklow (2005) & $0.15-0.8$ \\
\hline CANMX & Maximum canopy storage & $\mathrm{mm}$ & $2-6.5$ & Muleta and Nicklow (2005) & 1.9 \\
\hline SURLAG & $\begin{array}{l}\text { Surface runoff lag coeffi- } \\
\text { cient }\end{array}$ & & $0.53-4$ & Van Liew et al. (2005) & 0.75 \\
\hline
\end{tabular}

discharges during high water events. Table 8 shows the RMS error (RRMSE), absolute error (ABSERR), Nash-Sutcliffe's efficiency (EF), determination coefficient $\left(R^{2}\right)$, and percent of Bias (PBIAS) for the years 2000-2002.

Overall, calculated and measured discharges are well correlated. The model was able to reproduce the flow regime in the watershed.
The parameters involved in the computation of surface runoff in the Vergara watershed from precipitation data with SWAT are shown in Table 9. After calibration of the model following PARASOL (van Griensven and Bauwens, 2003), a modified range of SWAT parameters is obtained that better reproduce discharges from precipitation data in the study region. 


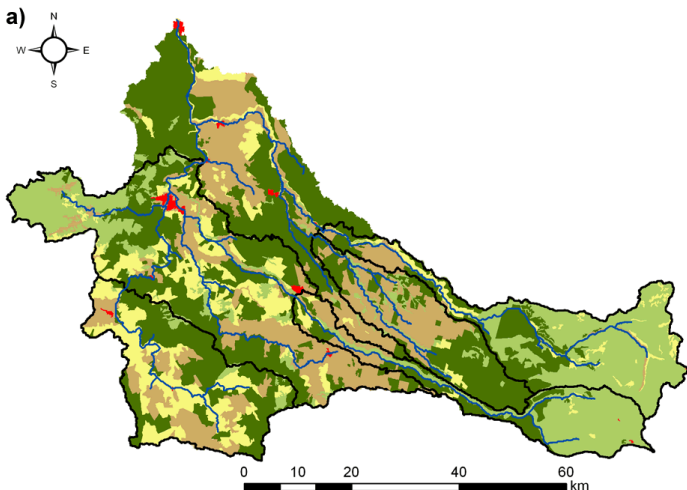

Baseline

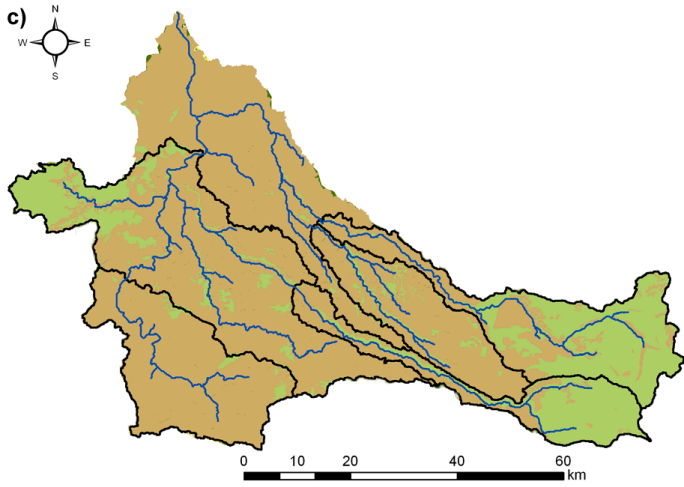

Scenario 2

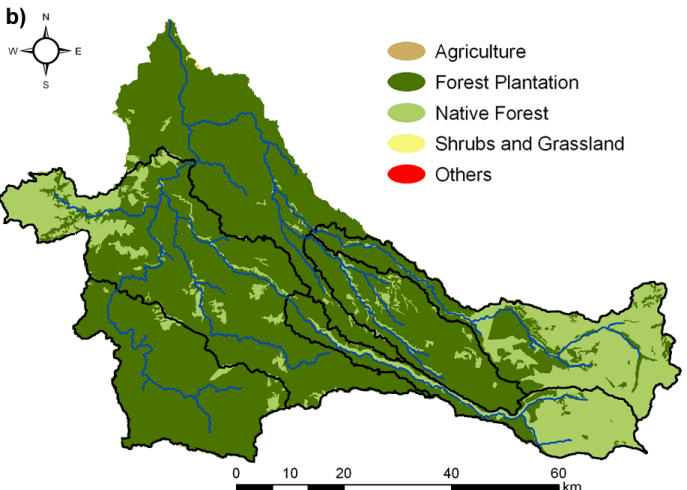

Scenario 1

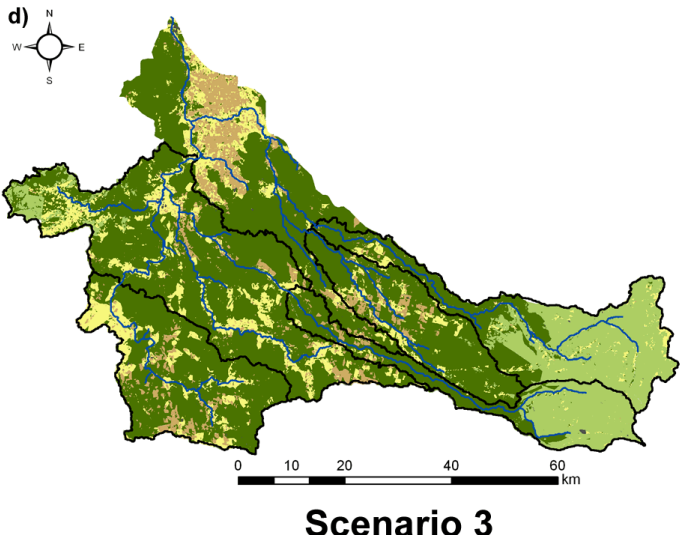

Scenario 3

Fig. 11. Land use maps according to observed scenario in year 1994 (a) baseline, (b) scenario 1, (c) scenario 2, (d) scenario 3.

Table 10. RMS error, absolute error, efficiency and determination coefficient calculated for the period 1977-1982.

\begin{tabular}{lccc}
\hline & Tijeral & Mininco & Malleco \\
\hline RRMSE & 0.39 & 0.61 & 0.44 \\
ABSERR & 11.76 & 5.27 & 7.96 \\
EF & 0.88 & 0.74 & 0.77 \\
$R^{2}$ & 0.91 & 0.79 & 0.80 \\
PBIAS & 10.95 & 19.47 & 17.15 \\
\hline
\end{tabular}

\subsection{Validation of the model}

Figure 9 shows the observed and computed discharges for years 1977-1982 at Tijeral, Mininco and Malleco, using the land use map of 1979. Note that gauge stations Renaico and Rehue did not operate in this period.

With the calibrated parameters, the model was able to correctly reproduce the order of magnitude of the observed discharges in the years 1977-1982, as well as their change tendency in time. Again, peak flows were not precisely reproduced by SWAT. Table 10 shows the RMS error, absolute
Table 11. RMS error, absolute error, efficiency, determination coefficient and percentage of Bias calculated for the period 1994-1999.

\begin{tabular}{lccccc}
\hline & Tijeral & Rehue $^{\mathrm{a}}$ & Mininco & Renaico & Malleco \\
\hline RRMSE & 0.31 & 0.63 & 0.33 & 0.42 & 0.38 \\
ABSERR & 8.24 & 2.15 & 2.98 & 9.12 & 5.07 \\
EF & 0.93 & 0.75 & 0.92 & 0.82 & 0.86 \\
$R^{2}$ & 0.93 & 0.89 & 0.94 & 0.83 & 0.88 \\
PBIAS & 2.77 & 32.75 & 9.13 & 7.88 & 10.38 \\
\hline
\end{tabular}

a Measured discharge data since July 1997

error, Nash-Sutcliffe's efficiency, determination coefficient, and percentage of bias calculated for the years 1977-1982.

Overall, simulated and observed discharges are well correlated. The model reproduced with sufficient efficiency the flow regime in the subbasins for the validation period. Figure 10 shows the observed and computed discharges for years 1994-1999 using the land use map of 1994.

The model was able to correctly reproduce the order of magnitude of the observed discharges, as well as their change 
Table 12. Percentage of area covered by the different land uses for the Vergara watershed and its subbasins: Tijeral, Rehue, Mininco, Renaico and Malleco in baseline and scenarios 1,2, and 3.

\begin{tabular}{llcccccc}
\hline & Land use & Tijeral & Rehue & Mininco & Renaico & Malleco & Vergara \\
\hline \multirow{5}{*}{ Baseline } & Agriculture & 20.92 & 22.22 & 39.12 & 6.48 & 11.89 & 21.11 \\
& Native forest & 22.64 & 3.07 & 9.49 & 61.03 & 60.25 & 23.37 \\
& Forestry plantation & 35.99 & 40.45 & 49.07 & 23.95 & 23.81 & 39.44 \\
& Shrubs and grassland & 19.72 & 33.90 & 2.31 & 5.33 & 3.79 & 14.46 \\
& Others & 0.74 & 0.36 & 0.00 & 3.21 & 0.25 & 1.62 \\
\hline \multirow{5}{*}{ Scenario 1 } & Agriculture & 0.00 & 0.00 & 0.00 & 0.00 & 0.00 & 0.00 \\
& Native forest & 22.64 & 3.07 & 9.49 & 61.03 & 60.25 & 23.37 \\
& Forestry plantation & 77.36 & 96.93 & 90.51 & 38.97 & 39.75 & 76.63 \\
& Shrubs and grassland & 0.00 & 0.00 & 0.00 & 0.00 & 0.00 & 0.00 \\
& Others & 0.00 & 0.00 & 0.00 & 0.00 & 0.00 & 0.00 \\
\hline \multirow{5}{*}{ Scenario 2 } & Agriculture & 77.36 & 96.93 & 90.51 & 38.97 & 39.75 & 76.63 \\
& Native forest & 22.64 & 3.07 & 9.49 & 61.03 & 60.25 & 23.37 \\
& Forestry plantation & 0.00 & 0.00 & 0.00 & 0.00 & 0.00 & 0.00 \\
& Shrubs and grassland & 0.00 & 0.00 & 0.00 & 0.00 & 0.00 & 0.00 \\
& Others & 0.00 & 0.00 & 0.00 & 0.00 & 0.00 & 0.00 \\
\hline \multirow{5}{*}{ Scenario 3 } & Forestry plantation & 67.53 & 81.29 & 32.92 & 72.84 & 42.94 & 62.87 \\
& Agriculture & 5.71 & 7.80 & 0.54 & 8.73 & 2.41 & 7.70 \\
& Shrubs and grassland & 15.12 & 9.86 & 6.10 & 18.30 & 2.47 & 13.26 \\
& Others & 0.12 & 0.07 & 0.04 & 0.13 & 0.24 & 0.15 \\
\hline
\end{tabular}

Table 13. Percentage of change respect to the baseline scenario for mean annual, wet season (May-October) and dry season (NovemberApril) flows.

\begin{tabular}{|c|c|c|c|c|c|c|c|c|c|c|c|c|c|c|c|c|c|c|}
\hline & \multicolumn{3}{|c|}{ Vergara } & \multicolumn{3}{|c|}{ Tijeral } & \multicolumn{3}{|c|}{ Rehue } & \multicolumn{3}{|c|}{ Mininco } & \multicolumn{3}{|c|}{ Renaico } & \multicolumn{3}{|c|}{ Malleco } \\
\hline & Year & Wet & Dry & Year & Wet & Dry & Year & Wet & Dry & Year & Wet & Dry & Year & Wet & Dry & Year & Wet & Dry \\
\hline Scenario 1 & -4.09 & -4.83 & 0.24 & -1.86 & -2.81 & 2.93 & -10.61 & -10.67 & -9.94 & -8.57 & -9.02 & -4.42 & -2.32 & -2.81 & 0.06 & -1.69 & -2.48 & 1.19 \\
\hline Scenario 2 & 5.08 & 5.41 & 3.06 & 7.30 & 7.28 & 6.32 & 7.23 & 7.70 & 1.55 & 2.38 & 2.63 & -1.06 & 1.13 & 1.27 & 0.81 & 1.86 & 1.37 & 3.86 \\
\hline Scenario 3 & -2.40 & -2.86 & 0.28 & -0.48 & -1.25 & 3.21 & -9.37 & -9.34 & -9.83 & -6.30 & -6.55 & -4.03 & -1.62 & -1.96 & 0.07 & -1.66 & -2.46 & 1.26 \\
\hline
\end{tabular}

tendency in time. Peak flows were not precisely reproduced by the model. Table 11 shows the RMS error, absolute error, Nash-Sutcliffe's efficiency, determination coefficient, and percentage of bias calculated for the years 1994-1998 at the different gauge stations.

The double validation process demonstrates that the model was able to compute the hydrologic response of the Vergara watershed under different land use scenarios with at least acceptable performance, i.e. EF $>0.75$. Thus, it is assumed that the model can be applied for analysis of the hydrologic response of the Vergara watershed to land use changes.

\subsection{Modelling the hydrologic response to land use changes}

The hydrologic response of the watershed to land use changes was simulated, maintaining the observed precipi- tation and ambient temperature for the years 1994-1999 as input. Consequently, each simulation differed from the baseline only in the land use conditions.

Figure 11 shows the 1994 land use map, i.e. baseline, and the three generated scenarios according to the described methodology. Note that land uses generated with the logistic regression model (Fig. 11, map d) show a strong growth of forest plantations over most part of the watershed, occupying agricultural areas and substituting native forest at the east hills of the Coastal Mountain Chain and the foothills of the Andes Mountain Chain. Table 12 indicates the percentage of area covered by the different land uses for the Vergara watershed and its subbasins: Tijeral, Rehue, Mininco, Renaico and Malleco in baseline and scenarios 1, 2, and 3 .

Figure 12 shows the changes of mean annual discharges at Tijeral, Rehue, Renaico, Mininco and Malleco under land use scenarios respect to the baseline. 


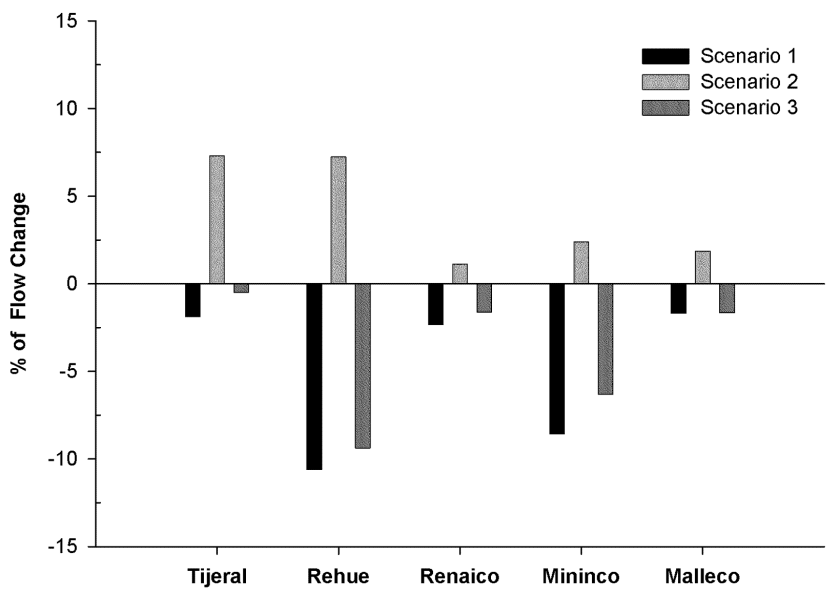

Fig. 12. Changes of mean annual discharges at Tijeral, Rehue, Renaico, Mininco and Malleco under land use scenarios respect to the baseline.

Mean annual discharge under land use scenarios 1 and 3 diminished in all the subbasins, with maximum reductions of ca. $10 \%$. Both scenarios represent land uses with predominant forest plantation. Land use scenario 2, representing a land use with predominant agricultural cover, caused an increase in annual mean discharge in all the subbasins up to ca. 7\% in Tijeral and Rehue. In general, forestry plantations tend to reduce mean annual discharge, whereas agriculture increases it. These results are in agreement with those obtained by (Hejazi and Moglen, 2008) for a watershed located in Thailand. Thus, implementation of protection laws for native species conservation and regulated land use change are strongly recommended in order to preserve the water resources of the watershed.

Table 13 shows a comparison of results obtained for the dry (mean values for November to April) and wet (mean values from May to October) season. Major relative changes in mean annual discharge are expected to occur at Rehue, followed by Malleco and Tijeral. Note that Rehue and Malleco are nested sub-basins of Tijeral.

\section{Conclusions}

The hydrologic response of a mesoscale watershed to different land use scenarios was analysed, applying heuristic rules and logistic regression models and the semi-distributed model SWAT. The Vergara's watershed response was analysed in terms of the annual mean discharge at the five subbasins gauged in the area which covered ca. $80 \%$ of the watershed.

The current model version successfully passed a double validation processes considering monthly outputs, with two different land use conditions. Calibration and validation of SWAT showed that it is able to reproduce the observed flows at Tijeral, Rehue, Mininco, Renaico and Malleco under different land use conditions satisfactorily.

Simulations of probable scenarios showed that substitution of agriculture areas, shrubs and grassland with plantations of introduced species cause a reduction of annual mean discharge in up to $10 \%$, while substitution of introduced forest plantations, shrubs and grasslands with agricultural land increases the annual mean discharge in up to $7 \%$. Based on the observed tendency of landuse change in the period 1979 1994, a reduction of the mean annual discharge is expected. Thus, forestation of areas with introduced species like Pinus radiata and Eucalyptus globulus might be regulated in order to protect the water resources of the watershed.

Acknowledgements. The authors thank the Chilean Research Council CONICYT for Grant FONDECYT 1090428.

Edited by: A. Bronstert

\section{References}

Aguayo, M., Pauchard, A., Azocar, G., and Parra, O.: Land use change in South-central Chile by the end of the XX century. Understanding spatial and temporary landscape dynamics, Rev. Chil. Hist. Nat., 82, 361-374. 2009 (in Spanish).

Allen, R. G., Pereira, L. S., Raes, D., and Smith, M.: Crop Evapotranspiration: Guidelines for Computing Crop Water Requirements, FAO Irrigat. Drainage, Rome, 1998.

Altamirano, A., Echeverría, C., and Lara, A.: Effect of forest fragmentation on the vegetation structure of threatened populations of Legrandia concinna (Myrtaceae) in the center-south of Chile, Rev. Chil. Hist. a Nat., 80, 27-42, 2007 (in Spanish).

Anderson, M. G. and Burt, T. P.: Process studies in hillslope hydrology, John Wiley and Sons Ltd, England, 1990.

Antonioletti, R., Gonzalez, P., and Ortega, S.: Comparative analysis of methods for estimating evapotranspiration in the Maule region of Chile, Agro-Ciencia (Chile), 14, 435-440, 1998 (in Spanish).

Arnold, J. C., Allen, P. M., and Bernhardt, G.: A comprehensive surface groundwater flow model, J. Hydrol., 142, 47-69, 1993.

Arnold, J. G., Allen, P. M. Muttiah, R., and Bernhardt, G.: Automated base flow separation and recession analysis techniques, Ground Water, 33, 1010-1018, 1995.

Arnold, J. G., Srinivasan, R., Muttiah, R. S., and Williams, J. R.: Large area hydrologic modeling and assessment - Part 1: Model development, J. Am. Water Resour. Assoc., 34, 73-89, 1998.

Arnold, J. G. and Allen, P. M.: Automated methods for estimating baseflow and ground water recharge from streamflow records, JAWRA, 35, 411-424, 1999.

Arnold, J. G., Muttiah, R. S., Srinivasan, R., and Allen, P. M.: Regional estimation of base flow and groundwater recharge in the upper Mississippi basin, J. Hydrol., 227, 21-40, 2000.

Arnold, J. G. and Fohrer, N.: SWAT2000: current capabilities and research opportunities in applied watershed modeling, Hydrol. Processes, 19, 563-572, 2005.

Bosch, J. M. and Hewlett, J. D.: A review of catchment experiments to determine the effect of vegetation changes on water yield and evapotranspiration, J. Hydrol., 55, 3-23, 1982. 
Breuer, L. and Huisman, J. A.: Assessing the impact of land use change on hydrology by ensemble modeling (LUCHEM), Adv. Water Resour., 32, 127-128, 2009.

Bronstert, A., Niehoff, D., and Burger, G.: Effects of climate and land-use change on storm runoff generation: present knowledge and modeling capabilities, Hydrol. Processes, 16, 509-529, 2002.

Brown, A. E., Zhang, L., McMahon, T. A., Western, A. W., and Vertessy, R. A.: A review of paired catchment studies for determining changes in water yield resulting from alterations in vegetation, J. Hydrol., 310, 28-61, 2005.

Centro de Información de Recursos Naturales (CIREN): Estudio Agrológico VIII Región. Descripción de Suelos, Materiales y símbolos. Tomos 1 y 2, CIREN CORFO, Santiago, Chile, 1999.

Centro de Información de Recursos Naturales (CIREN): Estudio Agrológico IX Región. Descripción de Suelos, Materiales y símbolos, CIREN CORFO, Santiago, Chile, 1999.

Corporación Nacional Forestal - Comisión Nacional del Medio Ambiente - Banco Interamericano de Reconstrucción y Fomento (CONAMA-CONAF-BIRF): Catastro y evaluación de los recursos vegetacionales nativos de Chile. Informe Regional, Octava Región, CONAF-CONAMA, Santiago, Chile, 1999.

Costa, M. H., Botta, A., and Cardille, J. A.: Effects of large-scale changes in land cover on the discharge of the Tocantins River, Southeastern Amazonia, J. Hydrol., 283, 206-217, 2003.

Croke, B. F. W., Merritt, W. S., and Jakeman, A. J.: A dynamic model for predicting hydrologic response to land cover changes in gauged and ungauged catchments, J. Hydrol., 291, 115-131, 2004.

Droogers, P. and Allen, R. G.: Estimating reference evapotranspiration under inaccurate data conditions, Irrigat. Drainage Syst., 16, 33-45, doi:10.1023/A:1015508322413, 2002.

Duan, Q., Sorooshian, S., and Gupta, V.: Effective and efficient global optimization for conceptual rainfall-runoff models, Water Resour. Res., 28, 1015-1031, 1992.

Echeverría C, Coomes, D., Salas, J., Rey-Benayas, J. M., Lara, A., and Newton, A.: Rapid deforestation and fragmentation of Chilean temperate forests, Biol. Conserv., 130, 481-494, 2006.

Echeverría, C., Newton, A., Lara, A., Rey-Benayas, J. M., and Coomes, D.: Impacts of forest fragmentation on species composition and forest structure in the temperate landscape of southern Chile, Global Ecol. Biogeogr., 16, 426-439, 2007.

Eckhardt, K., Breuer, L., and Frede, H. G.: Parameter uncertainty and the significance of simulated land use change effects, J. Hydrol., 273, 164-176, 2003.

Escobar, F. and Vidal, F.: Experience on the determination of the snowline in drainage basins of central Chile, Sociedad de Ingeniería Hidráulica Revista (Santiago), 2, 5-18, 1992 (in Spanish).

Fohrer, N., Haverkamp, S., Eckhardt, K., and Frede, H. G.: Hydrologic response to land use changes on the catchment scale, Physics Chem. Earth: B: Hydrol., Oceans Atmosphere, 26, 577582, 2001.

Fohrer, N., Haverkamp, S., and Frede, H. G.: Assessment of the effects of land use patterns on hydrologic landscape functions: development of sustainable land use concepts for low mountain range areas, Hydrol. Processes, 19, 659-672, 2005.

Foley, J. A., DeFries, R., Asner, G. P., Barford, C., Bonan, G., Carpenter, S. R., Chapin, F. S., Coe, M. T., Daily, G. C., Gibbs, H. K., Helkowski, J. H., Holloway, T., Howard, E. A., Kucharik, C.
J., Monfreda, C., Patz, J. A., Prentice, I. C., Ramankutty, N., and Snyder, P. K.: Global consequences of land use, Science, 309, 570-574, 2005.

Fontaine, T. A., Cruickshank, T. S., and Arnold, J. G.: Development of a snowfall - snowmelt routine for mountainous terrain for the soil water assessment tool (SWAT), J. Hydrol, 262, 209223, 2002.

Hejazi, M. I. and Moglen, G. E.: The effect of climate and land use change on flow duration in the Maryland Piedmont region, Hydrol. Processes, 22, 4710-4722, 2008.

Holvoet, K., van Griensven, A., Seuntjens, P., and Vanrolleghem, P. A.: Sensitivity analysis for hydrology and pesticide supply towards the river in SWAT, Phys. Chem. Earth, 30, 518-526, 2005.

Iroumé, A., Huber, A., Salazar, C., and Arriagada, A.: Monitoring and quantification of the hydric processes in an Andean watershed, IX Region, Chile, VI Jornadas del CONAPHI-Chile, Santiago, Chile, 1999 (in Spanish).

Jenerette, G. D. and Larsen, L.: A global perspective on changing sustainable urban water supplies, Global Planet. Change, 50, 202-211, 2006.

Jensen, M. E., Burman, R. D., and Allen, R. G.: Evapotranspiration and irrigation wáter requirements, ASCE Manuals and Reports on Engineering Practice, No. 70, ASCE, New York, USA, 332 pp, 1990.

Kannan, N., White, S., Worrall, F., and Whelan, M.: Modelling pollutants in runoff from the Colworth experimental Catchment, Proceedings of the 2nd International SWAT Conference, Bari, Italy, 149-154, 2003.

Kannan, N., White, S. M., Worrall, F., and Whelan, M. J.: Sensitivity analysis and identification of the best evapotranspiration and runoff options for hydrological modelling in SWAT-2000, J. Hydrol., 332, 456-466, 2007.

Klocking, B. and Haberlandt, U.: Impact of land use changes on water dynamics-a case study in temperate meso and macroscale river basins, Physics Chem. Earth: B: Hydrol., Oceans Atmosphere, 27, 619-629, 2002.

Klocking, B., Strobl, B., Knoblauch, S., Maier, U., Pfutzner, B., and Gericke, A.: Development and allocation of land-use scenarios in agriculture for hydrological impact studies, Physics Chem. Earth: B: Hydrol., Oceans Atmosphere, 28, 1311-1321, 2003.

Lahmer, W., Pfutzner, B., and Becker, A.: Assessment of land use and climate change impacts on the mesoscale, Physics Chem. Earth: B: Hydrol., Oceans Atmosphere, 26, 565-575, 2001.

Liu, Y. B., Gebremeskel, S., De Smedt, F., and Pfister, L.: Flood prediction with the WetSpa model on catchment scale, Flood Defence 2002, Wu, B. S., Wang, Z. Y., Huang, G. H., Fang, H. W., and Huang, J. C., Science Press, New York Ltd., ISBN 1-88013254-0, 2002.

Mark, A. F. and Dickinson, K. J. M.: Maximizing water yield with indigenous non-forest vegetation: a New Zealand perspective, Front. Ecol. Environ., 6, 25-34, 2008.

Montgomery, D. R. and Buffington, J. M.: Channel-reach morphology in mountain drainage basins, Geol. Soc. Am. Bull., 109, 596-611, 1997.

Morris, M. D.: Factorial sampling plans for preliminary computational experiments, Technometrics, 33, 161-174, 1991.

Naef, F., Scherrer, S., and Weiler, M.: A process based assessment of the potential to reduce flood runoff by land use change, J. Hydrol., 267, 74-79, 2002. 
Neitsch, S. L., Arnold, J. G., Kiniry, J. R., Srinivasan, R., and Williams, J. R.: Soil and Water Assessment Tool User's Manual Version 2000, Texas Water Resources Institute TR-192, College Station, TX., 2002.

Ott, B. and Uhlenbrook, S.: Quantifying the impact of land-use changes at the event and seasonal time scale using a processoriented catchment model, Hydrol. Earth Syst. Sci., 8, 62-78, doi:10.5194/hess-8-62-2004, 2004.

Peña, H., Vidal, F., Escobar, F., and Stowhas, L.: Snowmelt rates estimation, VII Congreso de Ingeniería Hidráulica, Concepción, Chile, 1985 (in Spanish).

Pizarro, R., Tapia, M., Román, L., Jordán, C., and Farías, C.: Chile. Instantaneous runoff coefficients for Tutuvén river basin, Maule Region, Chile, Bosque, 27, 83-91, 2006 (in Spanish).

Postel, S. L., Daily, G. C., and Ehrlich, P. R.: Human appropriation of renewable fresh water, Science, 271, 785-788, 1996.

Saavedra, C. and Stowhas, L.: Calculation and critical analysis of the curve number method for watershed of the country, XVI Congreso de Ingeniería Hidráulica, Santiago, Chile, 2003 (in Spanish).

Saghravani, S., Mustapha, S., Ibrahim, S., and Randjbaran, E.: Comparison of Daily and Monthly Results of Three Evapotranspiration Models in Tropical Zone: A Case Study, Am. J. Environ. Sci., 5, 698-705, 2009.

Sahin, V. and Hall, M. J.: The effects of afforestation and deforestation on water yields, J. Hydrol., 178, 293-309, 1996.

Spruill, C. A., Workman, S. R., and Taraba, J. L.: Simulation of daily and monthly stream discharge from small watersheds using the SWAT model, Trans. ASAE, 43, 1431-1439, 2000.

Stednick, J. D.: Monitoring the effects of timber harvest on annual water yield, J. Hydrol., 176, 79-95, 1996.

Stehr, A., Debels, P., Romero, F., and Alcayaga, H.: Hydrological modelling with SWAT under limited conditions of data availability: evaluation of results from a Chilean case study, J. Hydrol. Sci., 53, 588-601, 2008.

Stehr, A., Debels, P., Arumí, J. L., Romero, F., and Alcayaga, H.: Combining discharge data and MODIS imagery for evaluating the performance of SWAT and its snowmelt routine in a small Andean basin, Chile, J. Hydrol. Sci., 54, 1053-1067, 2009.
Stowhas, L.: Use of the curve number method in heterogenous watersheds, XVI Congreso de Ingeniería Hidráulica, Santiago, Chile, 2003 (in Spanish).

Thanapakpawin, P., Richey, J., Thomas, D., Rodda, S., Campbell, B., and Logsdon, M.: Effects of landuse change on the hydrologic regime of the Mae Chaem river basin, NW Thailand, J. Hydrol., 334, 215-230, 2007.

Uhlenbrook, S., Roser, S., and Tilch, N.: Development of a distributed, but conceptual catchment model to represent hydrological processes adequately at the meso scale, J. Hydrol., 291, 278296, 2004.

Veldkamp, A. and Lambin, E. F.: Predicting land-use change, Agric. Ecosyst. Environ., 85, 1-6, 2001.

Verburg, P. H., Soepboer, W., Veldkamp, A., Limpiada, R., Espaldon, V., and Mastura, S. S. A.: Modeling the spatial dynamics of regional land use: The CLUE-S model, Environ. Manage., 30, 391-405, 2002.

Van Griensven, A. and Bauwens, W.: Multiobjective autocalibration for semidistributed water quality models, Water Resour. Res., 39, 1348, doi:10.1029/2003WR002284, 2003.

Van Griensven, A., Meixner, T., Grunwald, S., Bishop, T., and Sirinivasan, R.: A global sensitivity analysis tool for the parameters of multi-variable catchment models, J. Hydrol., 324, 10-23, 2006.

Van Liew, M. W., Arnold, J. G., and Bosch, D. D.: Problems and potential of autocalibrating a hydrologic model, Trans. ASAE, 48, 1025-1040, 2005.

Van Roosmalen, L., Sonnenborg, T. O., and Jensen, K. H.: Impact of climate and land use change on the hydrology of a largescale agricultural catchment, Water Resour. Res., 45, W00A15, doi:10.1029/2007WR006760, 2009.

Vitousek, P. M., Mooney, H. A., Lubchenco, J., and Melillo, J. M.: Human domination of Earth's ecosystems, Science, 277, 494499, 1997.

Wilk, J., Andersson, L., and Plermkamon, V.: Hydrological impacts of forest conversion to agriculture in a large river basin in northeast Thailand, Hydrol. Processes, 15, 2729-2748, 2001. 